\title{
Soil Erosion and Land Degradation
}

\author{
Thomas Scholten * ${ }^{\mathbb{C}}$ and Steffen Seitz $\mathbb{B}$ \\ Soil Science and Geomorphology, Institute of Geography, University of Tübingen, 72070 Tübingen, Germany; \\ steffen.seitz@uni-tuebingen.de \\ * Correspondence: thomas.scholten@uni-tuebingen.de
}

Received: 15 October 2019; Accepted: 16 October 2019; Published: 22 October 2019

Land degradation by soil erosion is still one of the most severe environmental issues of our time. It is an insidious process removing the most productive soil layer first and able to cause decreasing productivity at hardly perceptible transport rates over longer periods of time. Although soil erosion is known and has been described for decades, humankind still faces numerous unresolved problems due to erosion worldwide, and many studies have found that the risk of soil loss increases significantly with ongoing climate change. Over the last decades, we observe more frequent extreme weather events such as thunderstorms, heavy rain, droughts, and heat waves. In combination with a steadily increasing world population and the need for food production-but also land use change e.g. by deforestation and intensification of agricultural land use in countries of the Global South, the risk of severe soil erosion is more than ever on the agenda for sustainable development.

Recent research in soil erosion has shown that not only topography and aboveground vegetation cover patterns shape the Earth's surface, but also land cover change, land use management, and engineering, play a decisive role in soil protection against erosion. Furthermore, the development and stabilization of new soil environments and the release, transportation, and storage of important environmental elements such as carbon are largely controlled by erosion. In this context, this special issue on Soil Erosion and Land Degradation contains a set of eight original manuscripts that addresses new findings on the above-mentioned issues as well as on methodological and technological advances and progress in modeling. Main topics are erosion measurements, modeling and prediction, matter transport, soil and land conservation, climate change, and erosion and sediment control.

In this line, Kinnell [1] gives an in-depth and comprehensive review of the science and logic in the so-called Universal Soil Loss Equation (USLE) family of models. Starting from the 1960s, the history and development of the USLE is described and analyzed in great detail and makes this paper a rich source of information for scientists but also for practitioners who apply the USLE and its derivates worldwide.

Following, Taghizadeh-Mehrjardi et al. [2] present a case study for soil erosion modeling from the Big Sioux River Watershed in the West Corn Belt of the USA, where the conversion of grasslands to cropland give cause for decreasing soil quality and crop productivity. Here, the Revised Universal Soil Loss Equation (RUSLE) was combined with latest Digital Soil Mapping (DSM) approaches to integrate spatial data on weather, topography, land use, and soil classes from easily available online sources.

The effect of land management on Andosols is addressed by Zemke et al. [3], who applied the physically-based soil erosion model WEPP (Water Erosion Prediction Project) together with comprehensive field sampling in a forested catchment in Germany. The focus of this study is on the role of clear-cutting and reforestation on backfilled soils after pumice excavation for runoff generation and soil erodibility.

An increasingly important management aspect to mitigate soil erosion on agricultural land is soil compaction in tramlines, as presented by Saggau et al. [4]. One main challenge is to quantify the effect of such tramlines on sediment transport on-site. In this respect, the process-based soil erosion model EROSION3D was applied with event-based rainfall at field scale using high-resolution grid cells. 
This approach allows to incorporate tramlines into soil erosion modeling and can serve as a valuable tool for allocating soil conservation measures.

Linear structures are also in the research focus of Rangel et al. [5]. Here, natural trails in forested mountain areas were monitored over time with micro-topography measurements in protected areas of the Serra da Bocaina National Park and the Serra do Mar State Park in south-east Brazil. Bioengineering techniques are recommended for trail managers in forest trail networks in Brazilian protected areas to overcome soil erosion on such trails.

Selective matter transport along slopes due to soil erosion is an upcoming topic. Jandl et al. [6] aim on partitioning soil organic matter (SOM) in hilly areas by soil erosion. Four catenae in the Baltic Sea catchment were analyzed regarding the amount and molecular-chemical composition of SOM in arable fields. Due to the heterogeneity along slopes, an adapted precise land management is recommended including amendment measures to specific field areas, such as shoulderslopes and backslopes.

Furthermore, Krenz et al. [7] investigate small scale heterogeneity of soil properties that have been caused during soil erosion processes. The study assesses the use of unmanned aerial vehicle (UAV) imagery in drylands to identify the degradation status of soils at high spatial resolution in the Klein Seekoei River basin in the Great Karoo Region of South Africa. Methodologically, they compare a conventional field-derived map with modelled maps based on UAV-derived data on vegetation cover and topographic features such as flow accumulation.

Finally, the work of Chalise et al. [8] gives an overview on land degradation by soil erosion in Nepal. This review includes land degradation studies on the role of high population growth, subsistence-based rural economy, and increasingly intense rainfall events in the monsoon season published in national and international journals and so-called grey literature. Further, the study gives an outlook on realistic plans to combat soil erosion including capacity building and participation of local stakeholders that can actively influence land management and degradation processes in Nepal.

We would like to thank all authors who have submitted their manuscripts to this appealing special issue on Soil Erosion and Land Degradation and all reviewers for their great engagement and intensive work during the review process.

Conflicts of Interest: The authors declare no conflicts of interest.

\section{References}

1. Peter, I.A.K. A Review of the Science and Logic Associated with Approach Used in the Universal Soil Loss Equation Family of Models. Soil Syst. 2019, 3, 62. [CrossRef]

2. Taghizadeh-Mehrjardi, R.; Bawa, A.; Kumar, S.; Zeraatpisheh, M.; Amirian-Chakan, A.; Akbarzadeh, A. Soil Erosion Spatial Prediction using Digital Soil Mapping and RUSLE methods for Big Sioux River Watershed. Soil Syst. 2019, 3, 43. [CrossRef]

3. Julian, J.; Zemke; Pöhler, J.; Stegmann, S. Modeling Runoff-Formation and Soil Erosion after Pumice Excavation at Forested Andosol-Sites in SW-Germany Using WEPP. Soil Syst. 2019, 3, 48. [CrossRef]

4. Saggau, P.; Kuhwald, M.; Duttmann, R. Integrating Soil Compaction Impacts of Tramlines into Soil Erosion Modelling: A Field-Scale Approach. Soil Syst. 2019, 3, 51. [CrossRef]

5. Rangel, L.; Jorge, M.D.C.; Guerra, A.; Fullen, M. Soil Erosion and Land Degradation on Trail Systems in Mountainous Areas: Two Case Studies from South-East Brazil. Soil Syst. 2019, 3, 56. [CrossRef]

6. Jandl, G.; Baum, C.; Heckrath, G.; Greve, M.H.; Kanal, A.; Mander, Ü.; Maliszewska-Kordybach, B.; Niedzwiecki, J.; Eckhardt, K.; Leinweber, P. Erosion Induced Heterogeneity of Soil Organic Matter in Catenae from the Baltic Sea Catchment. Soil Syst. 2019, 3, 42. [CrossRef] 
7. Krenz, J.; Greenwood, P.; Nikolaus, J.K. Soil Degradation Mapping in Drylands Using Unmanned Aerial Vehicle (UAV) Data. Soil Syst. 2019, 3, 33. [CrossRef]

8. Chalise, D.; Kristians, L.K.P. Land Degradation by Soil Erosion in Nepal: A Review. Soil Syst. $2019,3,12$. [CrossRef]

(c)

(C) 2019 by the authors. Licensee MDPI, Basel, Switzerland. This article is an open access article distributed under the terms and conditions of the Creative Commons Attribution (CC BY) license (http://creativecommons.org/licenses/by/4.0/). 